\title{
Chemical Composition and Amino Acid Content in Different Genotypes of Wheat Flour
}

\author{
Artiona Laze ${ }^{1 *}$, Valentina Arapi ${ }^{1}$, Evelina $\mathrm{Ceca}^{2}$, Kristi Gusho ${ }^{3}$, Lato Pezo ${ }^{4}$, Ferdi Brahushi5, \\ Desimir Kneževic ${ }^{6}$ \\ ${ }^{1}$ Department of Chemistry, Faculty of Biotechnology and Food, Agriculture University of Tirana, \\ Koder - Kames, 1001, Tirana, Albania \\ 2 College of Science and Mathematics, University of Massachusetts Boston, 62 Moffat Road, Quincy, MA 02169, Boston, MA, USA \\ 3 Faculty of Bioscience Engineering, Gent University, Coupure Links 653, 9000 Gent, Belgium \\ ${ }^{4}$ Institute of General and Physical Chemistry, Engineering Department, University of Belgrade, \\ Studentski trg 12/v, 1100 Belgrade, Serbia \\ ${ }^{5}$ Department of Agro-environment and Ecology, Agriculture University of Tirana, Koder - Kames, 1001, Tirana, Albania \\ ${ }^{6}$ Faculty of Agriculture, University of Pristina, Kosovska Mitrovica-Lesak, Kopaonicka bb, 38219 Lesak, Kosovo and Metohija, \\ Serbia \\ *Corresponding author, e-mail: alaze@ubt.edu.al
}

Received: 24 September 2018, Accepted: 01 March 2019, Published online: 10 May 2019

\begin{abstract}
The purpose of this study was to evaluate the chemical parameters and amino acid content in 10 genotypes of soft Albanian wheat organically grown and collected during the summer seasons of 2014. The thin layer chromatography method was used for the identification the content of amino acids and spectrophotometry was used to determine the concentration of indentified amino acids. The results exhibited high protein content (13.73 \% - 17.32 \%) and relative high content of total amino acid content (6.3 \% 10.9 \%). The most abundant of all amino acids was glutamic acid (in all genotypes) and cysteine (PZA 1, PZA 2, PZA 3, PZA 4, PZA 5 , PZA 6, PZA 7, and PZA 10).
\end{abstract}

Keywords

amino acids, chemical parameters, genotypes, wheat

\section{Introduction}

Bread, along with cereals is one of the most common products used in the human diet. However, cereals fail to supply a sufficient amount of certain essential nutrients such as amino acids, proteins, minerals and vitamins [1]. Generally, wheat flour contains about $70 \%$ starch, $2 \%$ lipids, $2 \%$ pentosanes and $12 \%$ moisture [2]. The main goal of wheat breeding and agronomic practices is increasing the grain production and enhancing its quality. The grain quality is determined by the content of organic compounds (protein and its fractions, carbohydrates and lipids), mineral nutrients (phosphorus, calcium, potassium, magnesium, and microelements), vitamins, antioxidants, and nutritional compounds [3]. These genetically determined traits of grain quality are influenced by the environmental conditions. The differences in protein content of grain can be caused by soil properties, weather condition over the breeding year [4] and wheat plantation [5]. The high temperature, sunlight and inadequate amount of precipitation during the grain filling stage increase the content of protein and gluten [4]. The "ash content" is the total quantity of minerals in a certain food sample.

The environmental variables and the agronomic measure did not have a significant effect on the ash content in flour, due to a high variation in traits [6]. Stability, appearance, texture and taste of food depend heavily on the amount of water in the wheat grains. Grains with high or very low moisture content commonly contribute towards loss in the quality. The moisture content of flour usually fluctuates from $1 \%$ to $15 \%$, depending upon the storage conditions and hygroscopic nature of the starch. Starch is the main component in wheat grain and it affects the structure of final products [7]. Starch is a polymer of glucose. At least two types of polymers are chemically distinguishable: amylose and amylopectin. Amylose is mostly a linear 
$\alpha-(1,4)$ - linked glucose polymer with a degree of polymerization (DP) of 1000-5000 glucose units. Amylopectin is branched to a much greater extent than amylose. So much that, on the average, the unit chain in amylopectin is only 20 - 25 glucose molecules long. Normal wheat starch contains $20 \%$ - $30 \%$ amylose and $70 \%$ - $80 \%$ amylopectin [8]. The starch granules undergo several changes during gelatinization, where the partial breakdowns of starch granules along with their swelling up to several times of their original size are the most important [9]. Cereals lipids originate from membranes, organelles and spherosomes and consist of different chemical structures. Depending on the extraction rate wheat flours contains $0.5 \%-3 \%$ lipids [10]. The germ has the highest amount of lipids (11\%), but significant amounts are also associated with the bran, the starch and proteins of the endosperms. Even in small amounts, lipids play an important role in bread making because of their ability to associate with proteins due to their amphipathic nature and with starch, forming inclusion complexes [11]. The effect of lipids was reviewed for the first time by Bell [12] who divided those effects into two types: chemical and physical effects. The chemical effect is lipid oxidation and the physical effects involve: lubrication, foam forming and involvement of hydrogen, hydrophobic bonds and delayed carbon dioxide release [13]. The content of protein in mature grain ranges from $8 \%$ to $20 \%$ and is the second major component of the endosperm. According to Arapi [14] the protein content in Albanian wheat ranged from $12.47 \%$ to 17 . $\%$, with an average value of $14.18 \%$, which is therefore considered a high value. Osborne classifies wheat protein according to the solubility: albumins are soluble in water; globulins are soluble in dilute $\mathrm{NaCl}$ solutions, gliadins which are soluble in $70 \%$ ethanol and glutenin which is soluble in dilute acid or alkali solution [15]. Glutenin and gliadins are recognized as a major wheat storage protein, constituting about $75 \%-85 \%$ of the total grain proteins [16] which have important roles in determining bread making quality [17]. From the nutrition point of view the albumins and globulins have a very good amino acid balance. They are relatively high in lysine, tryptophan (Trp) and methionine (Met). The contents of the lysine (Lys) and methionine are not at a satisfactory level achieved by the breeding of cereals. However, when combined with other food proteins such as legumes, oil seed or animal products the proteins of wheat exhibit excellent nutritional supplements. The main goals of this study were as follows: (i) to evaluate the chemical properties of 10 genotypes of Albanian wheat grown in organic condition; (ii) to determine the amino acid content as a nutritional value of wheat flour. Selected parameters are useful for selecting genotypes with high quality characteristics for further breeding in order to improve the nutritional value of the wheat flour used for human consumption.

\section{Materials and Methods}

\subsection{Plant and soil materials}

Ten soft wheat genotypes (PZA 1, PZA 2, PZA 3, PZA 4, PZA 5, PZA 6, PZA 7, PZA 8, PZA 9, PZA 10) were grown organically, during the year 2013-2014 in the Experimental Didactics Economy (E.D.E) of the Agricultural University of Tirana (latitude 41'19'39'N, longitude 1949'08' E; average altitude $89 \mathrm{~m}$ ). Each plot was planted in five rows; the plot size being $5 \mathrm{~m} \times 1.2 \mathrm{~m}$. Each of the wheat lines were planted in three replications according to the Randomized Block Scheme (RCBD). The monthly meteorological data for the period December -July was obtained from a meteorological station which was located in Tirana. The area has a warm Mediterranean climate, with an annual average temperature and rainfall of $13.7{ }^{\circ} \mathrm{C}$ and $591.6 \mathrm{~mm}$, respectively. The whole grain wheat flour samples were obtained by milling 10 genotypes of wheat on an experimental automatic mill (Fritch, Pulverisette 14). These materials were stored in vacuum packs and refrigerated at $-10{ }^{\circ} \mathrm{C}$ for further use. The soil reaction was slightly alkaline ( $\mathrm{pH}=7.80)$, the humus and nitrogen content were $2.20 \%$ and $0.15 \%$, respectively.

\subsection{Chemical analyses}

Moisture content, total protein, lipids and ash were determined according to AOAC [18]. The moisture content was determined by oven drying a sample at $60^{\circ} \mathrm{C}$ for 12 hours (AOAC, method 925, 40) [19], ash content was measured according to the dry ashing procedure (AOAC, Method $941,12)$, Protein content ( $\% \mathrm{~N} \times 5.7)$ was determined by the Kjedahl method (AOAC, Method 979, 09), and Lipid content was analyzed based on the Soxhlet extraction method utilizing n-hexane (AOAC, Method 4.5.01). The starch content was analyzed following the Megazyme Starch determination procedure (Megazyme International, Ireland, Ltd). All solution, reagents and buffers were prepared as described in the instruction given by Megazyme. All the samples were analyzed in triplicate.

\subsection{Amino acid content}

Identification of amino acids was done by using the method of chromatography [20]. 


\subsubsection{Wheat seed sample}

A wheat seed was milled and $0.5 \mathrm{~g}$ was used for the extraction of amino acids for all ten wheat genotypes.

\subsubsection{Extraction of amino acid}

The Amino acids were extracted from complex compounds of grain (carbohydrates, lipids, inorganic salts, etc.) by using $80 \%$ of ethanol and sedimentation of dissolved proteins by chloroform.

\subsubsection{Loading samples}

On the marked line at the prepared strip of absorbent Whatman paper, use a micropipette to put the small drop $(2 \mu \mathrm{l})$ of solution containing extracted amino acid. Repeat this 4 or 5 times, allowing the spot to dry each time aiming to keep the spot under $4 \mathrm{~mm}$ in diameter and build the concentration of the solution for analysis, without significantly enlarging the spot.

\subsubsection{Separation of amino acids}

The end of the absorbent paper with the loaded samples is then placed into developing solvent (butanol: acetic acid: water - 3:1:1), which flows upward along the paper by capillary action. The different amino acids move at different rates on the paper because of differences in their $\mathrm{R}$ groups. Chromatograms develop for $60-90$ minutes or until the solvent line is within $2.5 \mathrm{~cm}$ from the top of the paper. The paper was removed and the solvent front line was marked with a pencil. The paper was hanged on a wire.

\subsubsection{Staining of chromatograms}

In order to detect the location of the amino acids, the dried paper was sprayed with developer $0.2 \%$ solution of ninhydrin in $99 \%$ acetone $\left(0.2 \mathrm{~g}\right.$ of ninhydrin $+99 \mathrm{~cm}^{3}$ of acetone $+1 \mathrm{~cm}^{3}$ of distilled water). The wet ninhydrin chromatogram is first dried at room temperature and then placed in an oven for $5 \mathrm{~min}$., at $70^{\circ} \mathrm{C}$. The color developed by the individual spots were outlined and subsequently marked for photographic purposes. The color and intensity depend on the type and concentration of amino acids.

\subsubsection{Analysis of chromatogram}

The distance of the solvent migrated and the distance of each of the migrated amino acids were measured to find the ratio of the distance that the spot moves to the total distance the solvent front moves. Distances are measured to the center of the spots. This ratio is called the $R_{f}$ value and is defined as:
$R_{f}=\frac{\text { distance the amino acid migrated }}{\text { distance the solvent migrated }}$.

Identification of individual amino acids was conducted in comparison with the reference $\mathrm{Rf}$ value for each amino acid.

\subsubsection{Quantitative analysis}

The amino acid content, after separation by Thin Layer chromatography, is determined using spectrophotometrically, by measuring the extinction (absorbance) of the eluted solution of a stained spot on the particular wavelength.

\subsubsection{Elution of spots of amino acids on chromatogram}

The spots of amino acids in the chromatogram were cut into small pieces which transferred to tubes (volume of 10 $\mathrm{ml})$. In the tube $0.5 \mathrm{ml}$ of $1 \%$ solution of ninhydrin was added in a phosphate buffer $\mathrm{pH}$ 7. In this solution $5 \mathrm{ml}$ with water saturated n-butanol pH 7 was also added. (The neutralization of water saturated n-butanol is achieved by the careful addition of sodium hydroxide solution). The tubes are left to boil in a water bath for 20 minutes, and then cooled below the water jet to room temperature. Chilled tubes were filled with $10 \mathrm{ml}$ with water saturated n-butanol $(\mathrm{pH}=7)$ and shaken well. After being removed from the water bath and cooling. If the contents of the tube was hazy, in this case it was necessary to fill the test tube with $10 \mathrm{ml}$ of pure $\mathrm{n}$-butanol.

The method of spectrophotometry was used for establishing the concentration of identified amino acids. It measures the absorbance at $570 \mathrm{~nm}$. As a comparative solution, n-butanol is used.

The total concentration of free amino acids was determined through a standard curve line for tyrosine while the concentration for each amino acid was also determined through a standard curve line for glycine [21, 22].

\subsection{Statistical analyses}

Principal Component Analysis (PCA) is a mathematical procedure used as a central tool in chemometrics simulations, and represents a multivariate technique in which the simultaneous data reduction and classification is performed by transforming the data into orthogonal components that are linear combinations of the original variables [23]. PCA is done by Eigenvalue decomposition of the correlation matrix of the obtained data [24], which ensures that the first component will contain the largest possible 
variance. This analysis is generally used to achieve the maximum separation among clusters of parameters [25]. All determinations were made in triplicate. Analysis of variance (ANOVA) for comparison of sample means was used to analyze variations in observed parameters among the samples. All data was processed statistically using the software STATISTICA 10.0 (StatSoft Inc., Tulsa, OK, USA).

\section{Results and discussion}

\subsection{Chemical parameters}

The data obtained for 10 wheat genotypes are presented in Table 1 . The moisture content in the wheat genotypes usually ranged from $7.8 \%$ to $14.8 \%$ [26]. In the wheat genotypes analyzed in this study, the moisture content ranged from $10.43 \%$ (PZA 2) to $13.50 \%$ (PZA 8), which indicates that these genotypes can be stored for a longer time (Table 1).

The ash content is an important parameter in the milling industry; millers need to know the overall mineral content of the wheat to achieve a specific ash level in flour. Ash in the flour can affect the color of the finished product [27]. The ash content was found to be in the range of $1.45 \%$ (PZA 1) to $1.88 \%$ (PZA 9). In the following study the ash content is high because the whole wheat flour is being studied. Wheat is the most popular source of protein in the human diet. In this study the protein content in the whole wheat flour ranged from $13.35 \%$ (PZA 8) to $17.32 \%$ (PZA 4), with an average of $15.05 \%$. The highest protein content was established in PZA 4 (17.32\%) and PZA 7 (17.14\%), followed by PZA 5 (15.04\%) and PZA 2 (15.03\%). Environmental conditions and wheat genotypes are mostly responsible for protein content and those two factors have a major influence during the growth and development of the seed [28]. High temperature during the grain filling period influences grain protein content and composition; it increases the ratio between gliadin and glutenin, which represent weak dough traits [29, 30]. Its influence on decreasing starch deposition in grains [31] leads to more nitrogen per unit of starch [32]. The water deficit induces reduction in starch accumulation as well as grain yield during the grain filling phase [33]. It is known that salinity stress increases grain protein content by $18 \%$, wet gluten by $3 \%$, and dry gluten by $8 \%$ in durum wheat [34]. From the statistical results it is evident that the protein content was significantly affected by the wheat genotypes. The difference between genotypes may be due to variation in their genetic variability. The genotype PZA 8 had the highest starch content $(64.75 \%)$ while PZA 2 and PZA 4 had the lowest (53\%). The results obtained in this study are similar to the earlier studies [35] which reported variation in starch content from $60 \%-70$ $\%$ of the whole grain. The lipid content in ten genotypes of wheat ranged from $1.95 \%$ to $1.88 \%$. The highest lipid content was observed in three genotypes of wheat PZA 1, PZA 8 and PZA 10 (1.95\%), while the lowest lipid content was found in PZA 7 (1.88 \%) and PZA 9 (1.89\%). The statistical analysis of the lipid content demonstrates that there is no significant difference $(p<0.05)$ between genotypes of soft wheat. In this experiment, PCA was applied to analyze the similarities of the various wheat types, collected at different sampling sites. PCA was used to allow easy representation of observed parameters and different wheat samples in a two-dimensional diagram. The first two PCs were extracted and utilized in bivariate plots; loadings were considered to evaluate correlations between variables. Prior to PCA, the data sets were examined for outliers [36]. The PCA of the presented data explained that

Table 1 Chemical composition of 10 genotypes of wheat

\begin{tabular}{|c|c|c|c|c|c|}
\hline Genotype & Ash (\%) & Moisture (\%) & Protein $(\%)$ & Lipids (\%) & Starch (\%) \\
\hline PZA 1 & $1.45 \pm 0.01^{\mathrm{a}}$ & $12.27 \pm 0.15^{\mathrm{bc}}$ & $14.82 \pm 0.01^{\mathrm{ac}}$ & $1.95 \pm 0.01^{\mathrm{a}}$ & $56.00 \pm 0.82^{\mathrm{abc}}$ \\
\hline PZA 2 & $1.63 \pm 0.01^{\mathrm{c}}$ & $10.43 \pm 0.06^{\mathrm{f}}$ & $15.03 \pm 0.01^{\mathrm{a}}$ & $1.89 \pm 0.02^{\mathrm{a}}$ & $53.00 \pm 0.82^{\mathrm{a}}$ \\
\hline PZA 3 & $1.82 \pm 0.01^{\mathrm{e}}$ & $13.03 \pm 0.06^{\mathrm{d}}$ & $14.98 \pm 0.01^{\mathrm{a}}$ & $1.93 \pm 0.01^{\mathrm{a}}$ & $56.50 \pm 1.29^{\mathrm{bc}}$ \\
\hline PZA 4 & $1.74 \pm 0.01^{\mathrm{d}}$ & $11.73 \pm 0.15^{\mathrm{a}}$ & $17.32 \pm 0.01^{\mathrm{d}}$ & $1.92 \pm 0.02^{\mathrm{a}}$ & $52.75 \pm 0.50^{\mathrm{a}}$ \\
\hline PZA 5 & $1.56 \pm 0.02^{\mathrm{b}}$ & $12.10 \pm 0.26^{\mathrm{abc}}$ & $15.04 \pm 0.01^{\mathrm{a}}$ & $1.91 \pm 0.02^{\mathrm{a}}$ & $56.75 \pm 0.50^{\mathrm{bcd}}$ \\
\hline PZA 6 & $1.61 \pm 0.02^{\mathrm{c}}$ & $12.50 \pm 0.10^{\mathrm{c}}$ & $14.98 \pm 0.02^{\mathrm{a}}$ & $1.90 \pm 0.02^{\mathrm{a}}$ & $54.25 \pm 1.26^{\mathrm{ab}}$ \\
\hline PZA 7 & $1.57 \pm 0.01^{\mathrm{b}}$ & $13.20 \pm 0.10^{\mathrm{de}}$ & $17.14 \pm 0.02^{\mathrm{d}}$ & $1.88 \pm 0.02^{\mathrm{a}}$ & $62.75 \pm 0.96^{\mathrm{ef}}$ \\
\hline PZA 8 & $1.46 \pm 0.01^{\mathrm{a}}$ & $13.50 \pm 0.10^{\mathrm{e}}$ & $13.35 \pm 0.01^{\mathrm{b}}$ & $1.95 \pm 0.01^{\mathrm{a}}$ & $64.75 \pm 0.96^{f}$ \\
\hline PZA 9 & $1.88 \pm 0.01^{\mathrm{f}}$ & $11.97 \pm 0.15^{\mathrm{ab}}$ & $14.42 \pm 0.01^{\mathrm{c}}$ & $1.89 \pm 0.01^{\mathrm{a}}$ & $58.00 \pm 0.82^{\mathrm{cd}}$ \\
\hline PZA 10 & $1.47 \pm 0.01^{\mathrm{a}}$ & $13.27 \pm 0.06^{\mathrm{de}}$ & $13.73 \pm 0.57^{b}$ & $1.95 \pm 0.01^{\mathrm{a}}$ & $60.75 \pm 1.71^{\mathrm{de}}$ \\
\hline
\end{tabular}


the first two principal components accounted for $76.04 \%$ of the total variance ( $51.01 \%$ and $25.03 \%$, respectively) in the five variable spaces (the content of the ash, moisture, protein, lipids and starch). The points shown in the PCA graphics, which are geometrically close to each other, indicate the similarity of patterns that is represented by these points. The orientation of the vector describing the variable in factor space indicates an increasing trend of these variables, and the length of the vector is proportional to the square of the correlation values between the fitting value for the variable and the variable itself.

The angles between corresponding variables indicate the degree of their correlations (small angles corresponding to high correlations). Considering the map of the PCA performed on the data, moisture content, which contributed $34.5 \%$ of total variance, and starch content, which influenced $30.07 \%$ of the whole variance, exhibited positive scores according to first principal component, while the contents of ash $(9.9 \%)$, protein $(7.9 \%)$ and lipid content $(17.5 \%)$ showed a negative score according to the first principal component (Fig. 1). The content of ash contributed to $28.7 \%$ of the total variance (based on correlation) and the content of protein ( $32.8 \%$ ) contributed positively, while the content of lipid contributed negatively (33.0\%) for the calculation for the evaluation of the second principal component. The influence of the chemical parameters can be seen in Fig. 1, where the samples with higher ash and protein contents are located in the upper part of the graphic (samples 4, 3, 7 and 9), while sample 2, which is characterized with higher lipid content is located at the bottom part of the graphic. Samples 8 and 10 are located at the right side of the graphic as they demonstrate higher moisture and starch content.

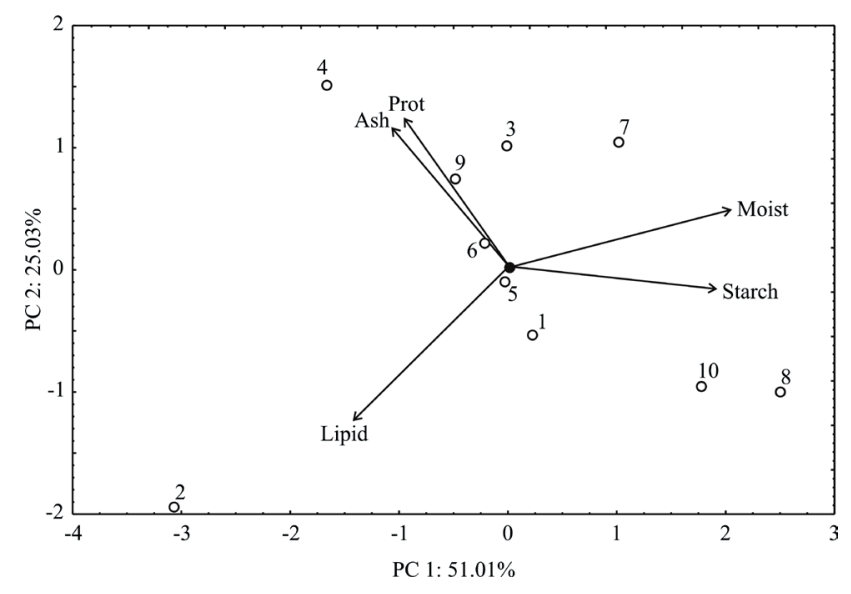

Fig. 1 PCA ordination of ash, moisture, protein, lipids and starch content
Table 2 The qualitative analyses of the amino acids in 10 genotypes of Albanian soft wheat

\begin{tabular}{|c|c|c|c|c|c|c|c|c|c|c|}
\hline \multirow{2}{*}{ Amino acids } & \multicolumn{10}{|c|}{ Samples (PZA) } \\
\hline & 1 & 2 & 3 & 4 & 5 & 6 & 7 & 8 & 9 & 10 \\
\hline Ornithine (Orn) & & + & & + & & + & + & & & \\
\hline Proline (Pro) & + & & & & & & & & + & + \\
\hline Oxy proline (Oxy) & & & & & & & & & + & \\
\hline Glutamic acid (Glu) & + & + & + & + & + & + & + & + & + & + \\
\hline Methionine (Met) & & & & & & & & & + & \\
\hline Tryptophan (Trp) & & & & & & & & + & + & + \\
\hline Phenylalanine (Phe) & & + & & & & & & & & \\
\hline B-alanine (B-Ala) & + & & & & & & & & & \\
\hline Cysteine (Cys) & + & + & + & + & + & + & + & & & + \\
\hline Arginine (Arg) & & + & & & & & & + & + & \\
\hline Lysine (Lys) & + & & + & & & & & + & + & + \\
\hline Asparagine (Asn) & + & & + & & + & & & + & & + \\
\hline Aspartic acid (Asp) & & & & + & & + & & & & \\
\hline
\end{tabular}

\section{Amino acid content}

Table 2 shows the qualitative analyses of the amino acids in ten genotypes of Albanian wheat. The amino acid content was also found to be affected by the wheat genotypes. In each of the examined genotypes, the different numbers of amino acids and different compositions of identified amino acids (Table 2) has been identified.

The most amino acids present in the analyzed genotypes of wheat were glutamic acid, cysteine, lysine and asparagine. The gluten protein consists of monomeric gliadins and polymeric glutenin, which are recognized as the major wheat storage proteins, are rich in asparagine, glutamine, arginine and proline [37] but very low in nutritional important amino acids lysine, tryptophan and methionine [38]. Humans and animals are able to synthesize nine non-essential amino acids out of the 20 amino acids. The remaining amino acids, which are considered essential amino acids, must be provided by foods. Among them cysteine (as well tyrosine) can be classified as semi-essential amino acids, because they can be synthesized only from Methionine and Phenylalanine [39]. The amino acid composition is important in determining the nutritional value of wheat for human and animal diets. The grain protein content and amino acid composition is determined by genetic factor (wheat genotype) and can change under the influence of environmental conditions (water, temperature). Wheat germs are a valuable component of functional foods because they present a high content of amino acids in protein [40] which can be used without 
Table 3 Total concentration of free amino acids in wheat grain

\begin{tabular}{lcc}
\hline Genotypes & $\begin{array}{c}\text { Concentration } \\
\left(\mathrm{mg} \mathrm{m}^{-1}\right)\end{array}$ & $\begin{array}{c}\text { Concentration } \\
(\%)\end{array}$ \\
\hline PZA 1 & 96.5 & 9.65 \\
PZA 2 & 109 & 10.9 \\
PZA 3 & 84 & 8.4 \\
PZA 4 & 99 & 9.9 \\
PZA 5 & 96 & 9.6 \\
PZA 6 & 88 & 8.8 \\
PZA 7 & 63 & 6.3 \\
PZA 8 & 93.5 & 9.35 \\
PZA 9 & 107 & 10.7 \\
PZA 10 & 78 & 7.8 \\
\hline
\end{tabular}

limits in animal feed. Environmental factors such as high temperature are associated with increased protein content in grain, but with decreased levels of essential amino acids [41]. The highest free amino acid content was established in PZA 2 (109 $\left.\mathrm{mg} \mathrm{ml}^{-1}\right)$ and PZA 9 (107 $\left.\mathrm{mg} \mathrm{ml}^{-1}\right)$, while the lowest free amino acid content was found in PZA 7 (63 $\mathrm{mg} \mathrm{ml}^{-1}$ ) (Table 3).

The PCA of the present data explains that the first two principal components accounted for $65.15 \%$ of the total variance ( $40.53 \%$ and $24.62 \%$, respectively) in the thirteen variables space (the content of Orn, Pro, Oxy, Glu, Met, Trp, Phe, $\beta$-Ala, Cys, Arg, Lys, Asn and Asp). Considering the map of the PCA performed on the data, Orn content, which contributed $12.4 \%$ of total variance, and Cys content, which influenced $12.6 \%$ of the whole variance, exhibited positive scores according to first principal component; while the contents of Lys (14.2\%), Pro (10.0\%), Trp (14.1\%), Oxy (10.5\%) and Met (10.5\%) showed a negative score according to the first principal component (Fig. 2). The content of Asn contributed

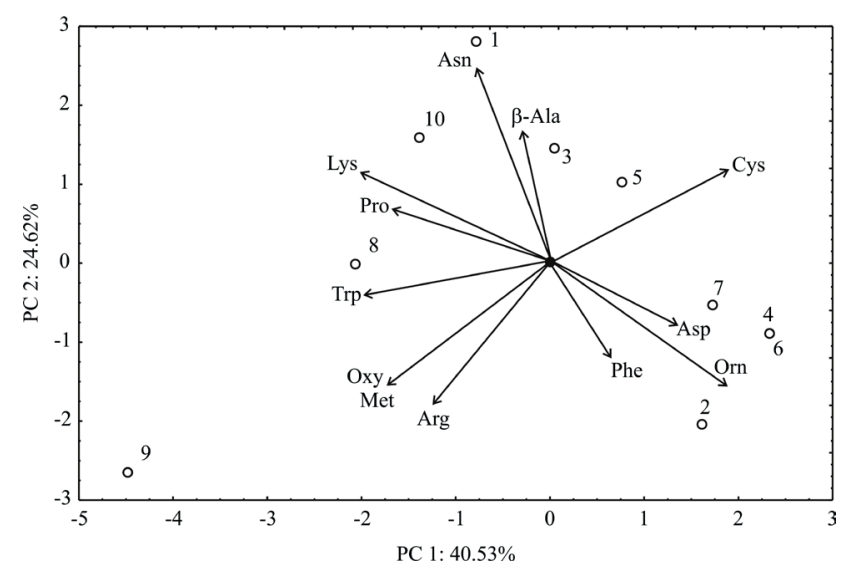

Fig. 2 PCA ordination of Orn, Pro, Oxy, Glu, Met, Trp, Phe, $\beta$-Ala, Cys, Arg, Lys, Asn and Asp content in samples. to $28.7 \%$ of the total variance (based on correlation) and content of $\beta$-Ala $(11.3 \%)$ contributed positively, while the content of Oxy (9.8\%), Met (9.8\%), Arg (13.1\%) and Orn $9.7 \%$ ) contributed negatively for the calculation for the evaluation of the second principal component. The influence of the chemical parameters can be seen in Fig. 2, where the samples with higher Asn and $\beta$-Ala contents are located in the upper part of the graphic (samples 1, 3 and 10), while sample 9, which is characterized with higher Oxy, Met and Arg content is located at the bottom part of the graphic. Sample 8 is located in the central part of the graphic, having higher Lys, Pro and Trp content. Samples 2, 4, 6, and 7 are located at the bottom right side of the graphic (higher Phe, Asp and Orn content).

Table 4 showed that different genotypes of wheat, demonstrated different contents of essential amino acids. Amino acid lysine was present in five analyzed genotypes (PZA 1, PZA 3, PZA 8, PZA 9, PZA 10), while amino acid tryptophan was present in three analyzed genotypes (PZA 8, PZA 9, PZA 10). The content of amino acid lysine ranged from $5.08 \%$ (PZA 1) to $10.13 \%$ (PZA 10), while amino acid tryptophan ranged from $1.11 \%$ (PZA 9) to $1.91 \%$ (PZA 10). The lysine content obtained in genotypes that were studied was higher than in wheat cultivars. The high level of lysine depends on the biosynthetic pathway in which enzymes aspartokinase (AK) and dihydrodipicolinate synthase (DHPS) play an important role. The increase of lysine synthesis can be achieved by expressing mutant enzymes (AK, DHPS) which are insensitive to lysine feedback inhibition [42]. This is achieved in seeds of high lysine maize [43]. Tryptophan plays a role as a precursor of the neurotransmitter serotonin and the epiphyseal hormone melatonin [44]. The tryptophan contents, obtained in the wheat genotypes that were analyzed, were

Table 4 Total content of essential amino acids (EAA) of the 10 genotypes of soft wheat.

\begin{tabular}{|c|c|c|c|c|}
\hline Genotypes & Met & Lysine & Phe & $\operatorname{Trp}$ \\
\hline PZA 1 & & 5.08 & & - \\
\hline PZA 2 & & & 1.51 & \\
\hline PZA 3 & & 8.93 & & \\
\hline \multicolumn{5}{|l|}{ PZA 4} \\
\hline \multicolumn{5}{|l|}{ PZA 5} \\
\hline \multicolumn{5}{|l|}{ PZA 6} \\
\hline \multicolumn{5}{|l|}{ PZA 7} \\
\hline PZA 8 & & 6.84 & & 1.18 \\
\hline PZA 9 & 0.92 & 9.72 & & 1.11 \\
\hline PZA 10 & & 10.13 & & 1.91 \\
\hline
\end{tabular}


lower than the content reported by Gafurova [45] (1.8\% to $2 \%$ ), higher than the content reported by Knežević [46] $(0.92 \%-1.0 \%)$, but similar to those reported by Comai [47] (on average $1.16 \%$ ).

In the cereal seeds of Albanian wheat genotypes, that were analyzed, only five genotypes established a presence of lysine whose content was found to be higher than in the majority of the research. Also, the nutritional quality of protein in analyzed wheat genotypes is limited to a low concentration of methionine, phenylalanine and tryptophane. In wheat cultivars, grown in Denmark [48], in the UK [45], in Poland [49], in Serbia [41], and in Romania [50] was found poor content of lysine and the remainder were essential amino acids. The present data explained that the first two principal components accounted for $76.54 \%$ of the total variance (53.92\% and $22.62 \%$, respectively) in the four variable spaces (the content of Met, Lys, Phe and Trp). Among the essential amino acids, Lys, Trp, and Met attracted the biggest attention, which are the most limiting in wheat as well as in other cereals used in human foods and animal feed worldwide. The lysine and methionine amino acids are synthesized from aspartic acid [35].

Considering the map of the PCA performed on the data, Phe content, which contributed $9.9 \%$ of total variance, exhibited positive scores according to the first principal components, while the contents of Lys (38.0\%), Phe (9.9\%) and $\operatorname{Trp}(33.2 \%)$ showed a negative score according to the principal component (Fig. 3). The content of Phe contributed to $79.8 \%$ of the total variance (based on correlation) and content of Met (18.5\%) contributed positively for the calculation of the evaluation of the second principal component (Fig. 3). The role of tryptophan is very important in increasing the growth of wheat [51], seed weight of wheat [52], as well as increasing chlorophyll a and chlorophyll b content, with no significant change in carotenoid content under saline environment [53]. The amino acids methionine and phenylalanine were presented only in two genotypes, PZA 9 and PZA 2, respectively. According to some authors $[51,56]$ cereal grain methionine is the first amino acid remaining as minimum. Phenylalanine is essential for growth and development and young children can consume small amounts. Genotype PZA 9, was characterized by the largest number of the determined essential amino acids (three), indicating high nutritional value. In gliadins storage protein, glutamic acid is presented as glutamine. In this study, glutamic acid was identified in all analyses genotypes (Table 5) and ranged from $5.96 \%$ (PZA 4) to $19.79 \%$ (PZA 5).

The content of glutamic acid in ten Albanian wheat genotypes that were analyzed was higher than the content (4.24-8.75\%) found in aestivum and durum wheat genotypes reported by Spychaj-Fabisiak [50]. Glutamic acid is synthesized in the body (non-essential amino acid) and has a main role in amino acid metabolism and in maintaining

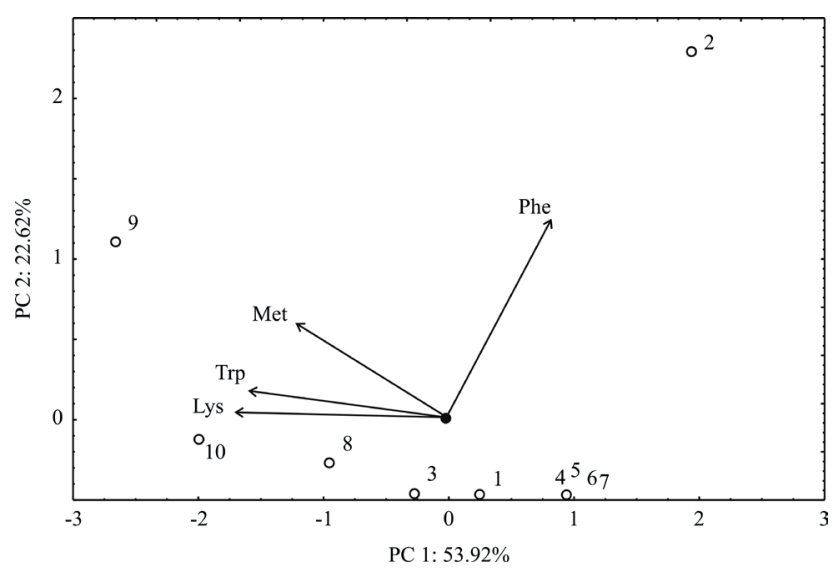

Fig. 3 PCA ordination of Met, Lys, Phe and Trp content in samples

Table 5 Total content of non-essential amino acids (NEAA) in grains of 10 wheat genotypes

\begin{tabular}{|c|c|c|c|c|c|c|c|c|c|c|}
\hline $\begin{array}{l}\mathrm{AA} \rightarrow \\
\downarrow \text { Lines }\end{array}$ & $\beta$-alanine & Proline & $\begin{array}{c}\text { Oxy } \\
\text { proline }\end{array}$ & Ornithine & Arginine & Aspartic acid & $\begin{array}{l}\text { Glutamic } \\
\text { acid }\end{array}$ & Asparagine & Cysteine & Citrulline \\
\hline PZA 1 & & 2.23 & & & & & 8.91 & 4.45 & 4.14 & \\
\hline PZA 2 & 5.18 & & & 2.66 & 4.31 & & 7.06 & & 5.23 & \\
\hline PZA 3 & & & & & & & 10.3 & 8.57 & 4.52 & \\
\hline PZA 4 & & & & 4.79 & & 7.07 & 5.96 & & 4.85 & \\
\hline PZA 5 & & & & & & & 19.79 & 9.50 & 8.96 & 3.28 \\
\hline PZA 6 & & & & 3.86 & & 5.90 & 6.36 & & 5.45 & \\
\hline PZA 7 & & & & 6.03 & & & 18.41 & & 6.8 & \\
\hline PZA 8 & & & & & 8.12 & & 9.79 & 8.40 & & \\
\hline PZA 9 & & 5.46 & 15.83 & & 9.80 & & 15.18 & & & \\
\hline PZA 10 & & 3.84 & & & & & 15.90 & 3.30 & 8.97 & \\
\hline
\end{tabular}


nitrogen balance in the body, which is essential in stress and illness situation. Glutamic acid (exists as glutamate) is a well-established excitatory neurotransmitter in the central nervous system.

Amino acid cysteine was identified in 8 genotypes of wheat (PZA 1, PZA 2, PZA 3, PZA 4, PZA 5, PZA 6, PZA 7, PZA 10) and ranged from $4.14 \%$ (PZA 1) to $8.97 \%$ (PZA 10). Synthesis of cysteine takes place in the endosperm and may limit the synthesis of sulfur-rich endosperm proteins, thus affecting flour quality, bread softness and nutritional value [57]. Cysteine is the limiting precursor to the production of glutathione, coenzyme A, taurine, and sulfite/sulfate. Amino acid asparagine was established in five genotypes of wheat (PZA 1, PZA 3, PZA 5, PZA 8, PZA 10). The highest content of the amino acid asparagine was established in genotype PZA 5 (9.50\%), followed by genotype PZA 8 (8.40\%), while the lowest content was found in genotype PZA 10 (3.30\%). Asparagine has a main role in nitrogen storage and transport in plants and accumulation in plant tissue under stress conditions that in harvested seeds is related to the formation of acrylamide in food. Amino acids arginine and proline were indentified in three genotypes of wheat. Amino acid ornithine was found in four genotypes of wheat (PZA 2, PZA 4, PZA 6, PZA 7) and the content ranged from $2.66 \%$ (PZA 2) to $6.03 \%$ (PZA 7). Amino acids $\beta$-alanine, oxy proline and citrulline were identified only in one genotype of wheat, PZA 2, PZA 9 and PZA 5, respectively (Table 5). Those concentrations were different in comparison to previous studies [50, 54]. It's known that nitrogen-containing compounds such as glutamine, asparagine, proline and ornithine accumulate in plants grown under environmental stress [55]. Also, glutamic acid can directly convert to proline. The PCA for non-essential amino acids (NEAA) explained that the first two principal components accounted for $59.66 \%$ of the total variance $(31.84 \%$ and $27.82 \%$, respectively) in the ten variables space (the content of $\beta$-Ala, Pro, Oxy, Orn, Arg, Asp, Glu, Asn, Cys and Cit). Considering the map of the PCA performed on the data, Arg content, which contributed $21.0 \%$ of total variance, Oxy content, which influenced $21.8 \%$, and Pro content $(18.4 \%)$, exhibited positive scores according to first principal component, while the contents of Asp (9.3\%), Orn (12.9\%) and Cys (13.1\%) showed a negative score according to the first principal component (Fig. 4).

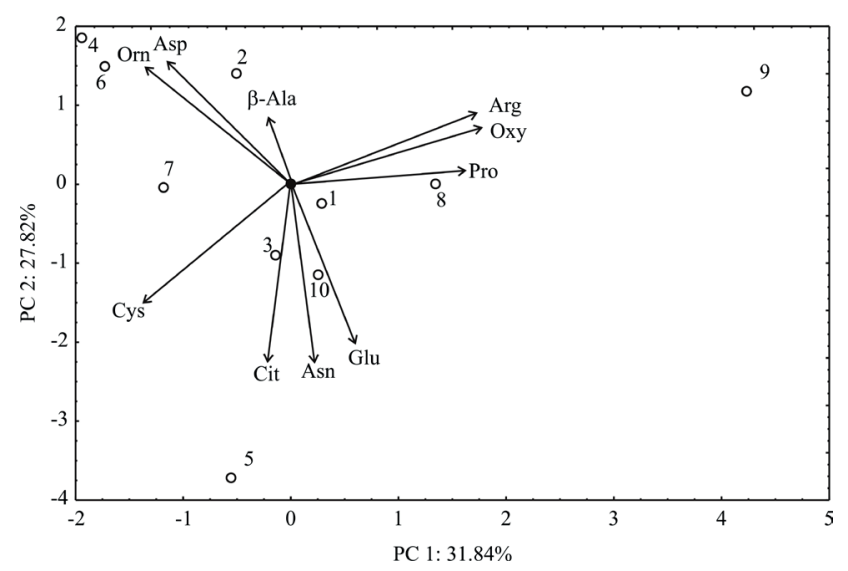

Fig. 4 PCA ordination of $\beta$-Ala, Pro, Oxy, Orn, Arg, Asp, Glu, Asn, Cys and Cit content

The content of Orn, which contributed $9.4 \%$ of the total variance (based on correlation) and the content of Asp $(10.3 \%)$ contributed positively, while the content of Cit (21.9\%), Asn (21.9\%), and Glu (17.8\%) contributed negatively for calculation of the evaluation of the second principal component (Fig. 4) The influence of the chemical parameters can be seen on Fig. 4, where the samples with higher Orn and Asp contents are located at the upper left part of the graphic (samples 2, 4 and 6), while sample 9, which is characterized with higher Oxy, Pro and Arg content is located at the right part of the graphic. Sample 5 is located at the bottom side of the graphic (higher Cit, Asn and Glu content).

\section{Conclusion}

Analyzed genotypes of soft wheat differ significantly $(\mathrm{P}<0.05)$ between each other in their content of ash, moisture, protein and starch. No significant differences among analyzed genotypes were found in lipid content $(\mathrm{P}<0.05)$. All genotypes of wheat were characterized by high values of protein content and an optimal level of starch and lipids. The concentration of the total amino acids varies from $63 \mathrm{mg} \mathrm{ml}^{-1}$ (PZA 7) to $109 \mathrm{mg} \mathrm{ml}^{-1}$ (PZA 2). Glutamic acid was presented in all the genotypes analyzed and had the highest concentration. The most presented essential amino acids were Lysine (PZA 1, PZA 3, PZA 8, PZA 9, and PZA 10) and Tryptophan (PZA 8, PZA 9, and PZA 10). The genotypes PZA 1, PZA 2, PZA 4, PZA 5, PZA 9, are characterized by high protein and amino acid content, indicating their high nutritional value. 


\section{References}

[1] Sands, D. C., Morris, C. E., Dratz, E. A., Pilgeram, A. L. "Elevating optimal human nutrition to a central goal of plant breeding and production of plant-based foods", Plant Science 177(5), pp. 377-389, 2009.

https://doi.org/10.1016/j.plantsci.2009.07.011

[2] Lásztity, R. "The Chemistry of Cereal Proteins", 2nd ed., CRC Press, New York, USA, 1995.

https://doi.org/10.1201/9780203737057

[3] Mallick, S. A., Azaz, K., Gupta, M., Sharma, V., Sinha, B. K. "Characterization of grain nutritional quality in wheat", Indian Journal of Plant Physiology, 18(2), pp. 183-186, 2013.

https://doi.org/10.1007/s40502-013-0025-z

[4] Jaskulska, I., Jaskulski, D., Gałezewski, L., Knapowski, T., Kozera, W., Wacławowicz, R. "Mineral Composition and Baking Value of the Winter Wheat Grain under Varied Environmental and Agronomic Conditions", Hindawi Journal of Chemistry, ID: 5013825, 2018. https://doi.org/10.1155/2018/5013825

[5] Zecevic, V., Boskovic, J., Knezevic, D., Micanovic, D. "Effect of seeding rate on grain quality of winter wheat", Chilean Journal of Agricultural Research, 74(1), pp. 23-28, 2014.

https://doi.org/10.4067/S0718-58392014000100004

[6] Alijošius, S., Svirmickas, G. J., Bliznikas, S. Gružauskas, R., Šašytè, V., Racevičiūtė-Stupelienè, A., Kliševičiūte, V., Daukšienè, A. "Grain chemical composition of different varieties of winter cereal", Zemdirbyste-Agriculture, 103(3), pp. 273-280, 2016.

https://doi.org/10.13080/z-a.2016.103.035

[7] Hoseney, R. C. "Principles of Cereal Science and Technology", 2nd ed., American Association of Cereal Chemists, St. Paul, USA, 1994. [online] Available at: https://eimbut.ga/principles-of-cereal-science.pdf [Accessed: 10 January 2017]

[8] Konik-Rose, C., Thistleton, J., Chanvrier, H., Tan, I., Halley, P., Gidley, M., Kosar-Hashemi, B., Wang, H., Larroque, O., Ikea, J., McMaugh, S., Regina, A., Rahman, S., Morell, M., Li, Z. "Effects of starch synthase IIa gene dosage on grain, protein and starch in endosperm of wheat", Theoretical and Applied Genetics, 115, pp. 1053-1065, 2007.

https://doi.org/10.1007/s00122-007-0631-0

[9] Ahmed, J., Auras, R. "Effect of hydrolysis on rheological properties of lentil starch slurry", LWT - Food Science and Technology, 44(4), pp. 976-983, 2011.

https://doi.org/10.1016/j.lwt.2010.08.007

[10] Gonzalez Thuillier, I., Salt, L., Chope, G., Penson, S., Skeggs, P., Tosi, P., Powers, S. J., Ward, J. L., Wilde, P., Shewry, P. R., Haslam, R. P. "Distribution of lipids in the grain of wheat (cv Hereward) determined by lipidomic analysis of milling and pearling fractions", Journal of Agricultural and Food Chemistry, 63(49), pp. 10705-10716, 2015.

http://doi.org/10.1021/acs.jafc.5b05289

[11] Singh, N., Singh, H., Bakshi, M. S. "Determining the distribution of ash in wheat using debranning and conductivity", Food Chemistry, 62(2), pp. 169-172, 1998. https://doi.org/10.1016/S0308-8146(97)00195-7
[12] Bell, B. M., Daniels, D. G. H., Fisher N. "Physical aspects of the improvement of dough by fat", Food Chemistry, 2(1), pp. 57-70, 1977. https://doi.org/10.1016/0308-8146(77)90008-5

[13] Toyosaki, T. "Effect of hydroperoxide in lipid peroxidation on dough fermentation", Food Chemistry, 104(2), pp. 680-685, 2007. https://doi.org/10.1016/j.foodchem.2006.12.031

[14] Arapi, V., Laze, A., Elezi, F., Bano, V. "Evaluation of some soft wheat Accessions of AUT collection created in the country, cased on qualitative indicators", Journal of International Environmental Application and Science, 8(4), pp. 658-662, 2013.

[15] Osborne, T. B. "The proteins of the wheat kernel", Carnegie Inst., Washington DC., USA, 1907. https://doi.org/10.5962/bhl.title.26152

[16] Belderok, B., Mesdag, H., Donner, D. A. "Bread-Making Quality of Wheat", Springer, New York, USA, 2000. https://doi.org/10.1007/978-94-017-0950-7

[17] Menkovska, M., Knežević, D., Ivanoksi, M. "Protein allelic composition, dough rheology and baking characteristics of flour mill streams from wheat cultivars with known and varied baking qualities", Cereal Chemistry, 79(5), pp. 720-725, 2002. https://doi.org/10.1094/CCHEM.2002.79.5.720

[18] AACC International Approved Methods "Method 44-19.01, 46-11.02, 58-99.01. ash, protein and lipids", AACC International, St. Paul, MN, USA, 2000.

[19] Association of Official Analytical Chemists (AOAC) "Official Methods of Analysis of AOAC International, 17th ed., No. 08-01 and No. 44-10", AOAC International, Gaithersburg, MD, USA, 1995.

[20] Grujic-Injac, B. "Chemistry of amino acid and proteins", Science book, Belgrade, Serbia, 1962.

[21] Trajkovic, J., Baras, J., Miric, M., Siler, S. "Analysis of food products", PhD Thesis, University of Belgrade, 1983.

[22] Džamić, M. "Protocols in Biochemistry", Science book, Belgrade, Serbia, 1989.

[23] Lee, D. E., Shin, G. R., Lee, S., Jang, E. S., Shin, H. W., Moon, B. S., Lee, C. H. "Metabolomics reveal that amino acids are the main contributors to antioxidant activity in wheat and rice gochujangs (Korean fermented red pepper paste)", Food Research International, 87, pp. 10-17, 2016. https://doi.org/10.1016/j.foodres.2016.06.015

[24] Janić-Hajnal, E., Čolović, R., Pezo, L., Orčić, D., Vukmirović, Đ., Mastilović, J. "Possibility of Alternaria toxins reduction by extrusion processing of whole wheat flour", Food Chemistry, 213, pp. 784-790, 2016. https://doi.org/10.1016/j.foodchem.2016.07.019

[25] Pontonio, E., Nionelli, L., Curiel, J. A., Sadeghi, A., Di Cagno, R., Gobbetti, M., Rizzello, C. G. "Iranian wheat flours from rural and industrial mills: Exploitation of the chemical and technology features, and selection of autochthonous sourdough starters for making breads", Food Microbiology, 47, pp. 99-110, 2015. https://doi.org/10.1016/j.fm.2014.10.011

[26] Qamar, M. I. "Development of minerals enriched brown flour by utilizing wheat milling by products", MSc Thesis, University of Agriculture, Faisalabad, Pakistan, 2002. 
[27] Keran, H., Salkic, M., Odobasic, A., Jasic, M., Ahmetovic, N., Sestan, J. "The Importance of Determination of some Physical Chemical Properties of Wheat and Flour", Agriculturae Conspectus Scientificus, 74(3), pp. 197-200, 2009. [online] Available at: https://acs.agr.hr/acs/index.php/acs/article/view/450 [Accessed: 10 January 2017]

[28] OECD "Rising food prices: Causes and consequences", 2003. [online] Available at: http://www.oecd.org/dataoecd/54/42/40847088.pdf [Accessed: 30 January 2018]

[29] Blumenthal, C. S., Barlow, E. W. R., Wrigley, C. W. "Growth environment and wheat quality: The effect of heat stress on dough properties and gluten proteins", Journal of Cereal Science, 18(1), pp. 3-21, 1993.

https://doi.org/10.1006/jcrs.19931030

[30] Yang, F., Jørgensen, A. D., Li, H., Søndergaard, I., Finnie, C., Svensson, B., Jiang, D., Wollenweber, B., Jacobsen, S. "Implications of high-temperature events and water deficits on protein profiles in wheat (Triticum aestivum L. cv. Vinjett) grain", Proteomics, 11(9), pp. 1684-1695, 2011.

https://doi.org/10.1002/pmic.201000654

[31] Spiertz, J. H. J., Hamer, R. J., Xu, H., Primo-Martin, C., Don, C., van der Putten, P. E. L. "Heat stress in wheat (Triticum aestivum L.): Effects on grain growth and quality traits", European Journal of Agronomy, 25(2), pp. 89-95, 2006.

https://doi.org/10.1016/j.eja.2006.04.012

[32] Keeling, P. L., Banisadr, R., Barone, L., Wasserman, B. P., Singletary, G. W. "Effect of temperature on enzymes in the pathway of starch biosynthesis in developing wheat and maize grain", Australian Journal of Plant Physiology, 21(6), pp. 807-827, 1994. https://doi.org/10.1071/PP9940807

[33] Garcia del Moral, L. F., Boujenna, A., Yanez, J. A., Ramos, J. M. "Forage production, grain yield and protein content in dual purpose triticale grown for both grain and forage", Agronomy Journal Abstract, 87(5), pp. 902-908, 1995. https://doi.org/10.2134/agronj1995.00021962008700050021x

[34] Houshmand, S., Arzani, A., Maibody, S. A. M. Feizic, M. "Evaluation of salt-tolerant genotypes of durum wheat derived from in vitro and field experiments", Field Crops Resources, 91(23), pp. 345-354, 2005.

https://doi.org/10.1016/j.fcr.2004.08.004

[35] Shewry, P. R. "Wheat gluten proteins", In: Shewry, P. R., Lookhart, G. L. (eds.) Wheat Gluten Protein Analysis, 12th ed., AACCI, St. Paul, MN, USA, 2003, pp. 1-17.

[36] Brlek, T., Pezo, L., Voća, N., Krička, T., Vukmirović, Đ., Čolović, R., Bodroža-Solarov, M. "Chemometric approach for assessing the quality of olive cake pellets", Fuel Processing Technology, 116, pp. 250-256, 2013. https://doi.org/10.1016/j.fuproc.2013.07.006

[37] Kirkman, M. A., Shewry, P. R., Miflin, B. J. "The effect of nitrogen nutrition on the lysine content and protein composition of barley seeds", Journal of the Science of Food and Agriculture, 33(2), pp. $115-127,1982$. https://doi.org/10.1002/jsfa.2740330203
[38] Shewry, P. R. "Improving the protein content and composition of cereal grain", Journal of Cereal Science, 46(3), pp. 239-250, 2007. https://doi.org/10.1016/j.jcs.2007.06.006

[39] Boisen, S., Hvelplund, T., Weisbjerg, M. R. "Ideal amino acid profiles as a basis for feed protein evaluation", Livestock Production Science, 64(2-3), pp. 239-251, 2000. https://doi.org/10.1016/S0301-6226(99)00146-3

[40] Sidhu, J. S., Kabir, Y., Hoffman, F. G. "Functional foods from cereal grain", International Journal of Food Properties, 10(2), pp. 231-244, 2007. https://doi.org/10.1080/10942910601045289

[41] Dias, A. S., Bagulho, A. S., Lidon, F. C. "Ultrastructure and biochemical traits of bread and durum wheat grains under heat stress", Brazilian Society of Plant Physiology, 20, pp. 323-333, 2008. [online] Available at: http://www.scielo.br/pdf/bjpp/v20n4/ a08v20n4.pdf [Accessed: 30th January 2018]

[42] Houmard, N. M., Mainville, J. L., Bonin, C. P., Huang, S., Luethy, M. H. Malvar, T. M. "High-lysine corn generated by endosperm-specific suppression of lysine catabolism using RNAi", Plant Biotechnology Journal, 5(5), pp. 605-614, 2007. https://doi.org/10.1111/j.1467-7652.2007.00265.x

[43] Tang, G., Galili, G., Zhuang, X. "RNAi and microRNA: breakthrough technologies for the improvement of plant nutritional value and metabolic engineering", Metabolomics, 3(3), pp. 357$369,2007$.

https://doi.org/10.1007/s11306-007-0073-3

[44] Schaechter, J. D., Wurtman, R. J. "Serotonin release varies with brain tryptophan levels", Brain Research, 532(1-2), pp. 203-210, 1990. https://doi.org/10.1016/0006-8993(90)91761-5

[45] Gafurova, D. A., Kasymova, T. D., Tursunkhodzhaev, P. M., Yuldashel, P. K. "Fractional and amino acids composition of wheat grain Cultivated in Usbekistan", Chemistry of Natural Compounds, 38(5), pp. 462-465, 2002. https://doi.org/10.1023/A:1022167811596

[46] Knežević, D., Mihajlović, D., Kondić, D. "Contents of Amino acids in grains of different bread wheat genotypes", Agroznanje/ Agro-knowledge Journal, 14(3), pp. 431-439, 2013. https://doi.org/10.7251/AGREN1303431K

[47] Comai, S., Bertazzo, A., Bailoni, L., Zancato M., Costa., C.V.L., Allegri, G. "Non-protein (free protein-bound) tryptophan content in cereal and legume seed flour", International Congress Series, 1304, pp. 227-232, 2007.

https://doi.org/10.1016/j.ics.2007.07.007

[48] Serena, A., Bach Knudsen, K. E. "Chemical and physicochemical characterisation of co-products from the vegetable ford and agro industries", Animal Feed Science and Technology, 139(1-2), pp. 109-124, 2007. https://doi.org/10.1016/j.anifeedsci.2006.12.003

[49] Kowieska, A., Lubowicki, R. Jaskowska, I. "Chemical composition and nutritional characteristics of several cereal grains". Acta Scientinarum Polonorum, Zootechnica, 10(2), pp. 37-50, 2011. [online] Available at: http://bwmeta1.element.dl-catalog-d4adaf9a-f43a-4baf-8dde-c4760ab85425 [Accessed: 30th January 2018] 
[50] Spychaj-Fabisiak, E., Ralcewicz, M., Knapowski, T., Kozera, W., Barczak, B., Nowak, K., Majcherczak, E., Murawska, B., Janowiak, J. "Effect of foliar fertilizationwith nitrogen and magnesium on chemical composition, biological value and bacing quality of spring wheat grain", In: Śliwińska, E., Spychaj-Fabisiak, E. (eds.) Understanding the Requirements for Development of Agricultural Production and of Rural Areas in the KuyavianPomeranian Province as a Result of Scientific Research, 1st ed., University of Technology and Life Sciences Press, Bydgoszcz, Poland, 2009, pp. 359-374.

[51] Mohite, B. "Isolation and characterization of indole acetic acid (IAA) producing bacteria from rhizospheric soil and its effect on plant growth", Journal of soil science and plant nutrition, 13(3), pp. 638-649, 2013.

https://doi.org/10.4067/S0718-95162013005000051

[52] Hassan, U. T., Bano, A. "Role of plant growth promoting rhizobacteria and L-tryptophan on improvement of growth, nutrient availability and yield of wheat (Triticum aestivum) under salt stress", International Journal of Agronomy and Agricultural Research (IJAAR), 4(2), pp. 30-39, 2014.

[53] El-Bassiouny, H. M. S. "Physiological Responses of Wheat to Salinity Alleviation by Nicotinamide and Tryptophan", International Journal of Agriculture \& Biology, 7(4), pp. 653-659, 2005. [online] Available at: http://www.fspublishers.org/published_papers/52624_..pdf [Accessed: 10 January 2017]
[54] Hassanein, R. A., El-Khawas, S. A., Ibrahim, S. K., El-Bassiouny, H. M., Mostafa, H. A., Abd El-Monem, A. A. "Improving the thermo tolerance of wheat plant by foliar application of arginine or putrescine", Pakistan Journal of Botany, 45(1), pp. 111-118, 2013. [online] Available at: https://www.pakbs.org/pjbot/PDFs/45(1)/14. pdf [Accessed: 10 January 2017]

[55] Lea, P. J., Sodek, L., Parry, M. A. J., Shewry, P. R., Halford, N. G. "Asparagine in plants", Annals of Applied Biology, 150(1), pp. 1-26, 2007. https://doi.org/10.1111/j.1744-7348.2006.00104.x

[56] Majcherczak, E., Cwojdzińsk, i W., Nowak, K. "Effect of increasing nitrogen fertilisation on the amino acid composition of winter barley grain protein", Acta Scientiarum Polonorum, Agricultura, 2(2), pp. 11-18, 2003.

[57] Dupont, F. M. "Metabolic pathways of the wheat (Triticum aestivum) endosperm amyloplast revealed by proteomics", BMC Plant Biology, 8(39), pp. 1-18, 2008. https://doi.org/10.1186/1471-2229-8-39 